\title{
B.В. КОПЧА
}

Василь Васильович Копча, кандидат юридичних наук, доцент ДВНЗ «Ужгородський національний університет»*

ORCID: 0000-0001-9888-1464

\section{МЕТОДОЛОГІЯ ДОСЛІДЖЕННЯ ПРАВОВОГО ЯВИЩА: ПОНЯТТЯ, СТРУКТУРА, ІНСТРУМЕНТАРІЙ}

Постановка проблеми. Адекватні результати будь-якого дослідження можуть бути отримані виключно за умови вживання дослідником дієвої методології. Не є винятком і сучасні правові дослідження, актуальність яких істотно зростає на початку XXI століття. Своєчасність дослідження цієї теми вимірюється різнопланово. По-перше, тривалий час в рамках правничої науки проблематика методології правового дослідження явно недооцінювалося. Хоча публікацій з тематики було чимало, основні проблеми методології дослідження не були вирішені. По-друге, в останні десятиліття в Україні насправді поступово змінюється парадигма праворозуміння, яка створює теоретичне та філософське підгрунтя для формування нової методології дослідження правових явищ. По-третє, предмет юриспруденції (правова реальність) зазнав істотних змін, що спричинило активний пошук нових методологічних інструментів пізнання.

Аналіз останніх досліджень і публікацій. В останні роки правнича наука більш активно опрацьовує проблеми методології правового дослідження. Серед таких публікацій можуть названі праці В. Братасюка1, А. Фальковського 2,3, О. Сердюка 4 , В. Дудченко ${ }^{5}$, М. Кельмана 6 , О. Данильяна 7 та інших. Однак науковий доробок істотно не применшує актуальність продовження досліджень різних аспектів методології правового дослідження.

Формулювання мети статті. Метою цієї статті є аналіз методології дослідження правового явища в таких iï аспектах: а) з'ясування основних підходів до розуміння методології та ііі співвідношення 3 методикою дослідження; б) дослідження обсягу та структури відповідного поняття; в) окреслення основних методів дослідження.

Виклад основного матеріалу. Одним із перших факторів методології правового дослідження є окреслення типу праворозуміння, характерного для даної правової системи. Слід погодитися, що спроби науковців дати просту відповідь про природу права неминуче приречені на провал, відтак, у майбутньому можна прийти до певного плюралізму інтегральності - такого інтегративного праворозуміння, яке поєднає, синтезує плюральні підходи до пізнання права 8 .

Також тривають дискусії щодо можливості створення універсальної теорії права i, як зазначають учені, основна причина такої складності - різноманіття філософських і теоретичних концепцій права. О. Мережко зазначає з цього приводу, що, власне, тут постає одвічне питання - що таке право? Єдиної відповіді на нього сьогодні просто немає; але ж без вирішення цього основного питання вибудувати метатеорію права просто неможливо. На його ж думку, юристи, які спеціалізуються в галузі національного права, і юристи-міжнародники уособлюють різні типи юридичного мислення. Якщо юрист, фахівець у галузі національного права, орієнтується у своєму мисленні на волю держави, то юрист-міжнародник виходить з ідеї міжнародної спільноти ${ }^{9}$.

Саме розуміння «методології права» і «правових методів» не є однозначним. Власне, метод дослідження найчастіше розуміється як «шлях до чогось», процедура дослідження. Йдеться про певні дії, які спрямовані певними принципами на досягнення поставленої мети. Натомість поняття «методології» сприймається як наука про методи, вчення про способи пізнання. У широкому сенсі - це наука про обгрунтування наукових знань та побудови наукових систем. Методологія права є складовою юридичної науки, виходячи 3 того, що вона є системою знань, яка включена до певної пізнавальної системи. Водночас варто погодитися, що теоретична юридична наука жодним чином не залежить від позитивного права, оскільки вона створює об'єктивні знання того, який має бути закон, без підпорядкування авторитету закону. Звісно, ці знання є лише науковими знаннями, а не довільним виправленням чинного закону. Йдеться про привілей і найважливіше завдання будь-якої реальної науки не приймати державних позицій (законодавчих, виконавчих чи судових) стосовно того, що є правильним ${ }^{10}$.

До методології правового дослідження є можливість підійти також з інших аспектів. У літературі зазначається, зокрема, що методологія - це наукова дисципліна, яка стосується визначення та систематизації методів, тобто відповідних способів розпізнавання предмета дослідження. Відтак, правова методологія - це наукова дисципліна, що займається методами розрізнення права та правових явищ. Разом із тим, методика проведення правового дослідження охоплює відповіді на наступні запитання: Як підібрати тему? Як знайти відповідні матеріали - наприклад, джерела права + судову практику? Як скласти план роботи? Як писати? Як цитувати? Скільки має бути глав (підрозділів)? Як зробити конспект? Як дослідити мою тему? Окремим

(C) В.В. Копча, 2020

* Vasyl Kopcha, Ph.D. in Law, Associate Professor, Associate Professor of Uzhgorod National University 
питанням є набір класичних методів опрацювання емпіричних джерел, зокрема: 1) метод опису. Описові дослідження, як випливає із назви, описують стан справ, який існує в даний час. Він просто описує явище чи ситуацію, що вивчається, та їхні характеристики. Методи, які зазвичай використовуються в описових дослідженнях, це методи опитування всіх видів, включаючи порівняння та фактичні запити різних видів; 2) метод концептуального аналізу. Концептуальне дослідження пов'язане $з$ якоюсь абстрактною ідеєю або теорією. Його зазвичай використовують філософи та мислителі для розробки нових концепцій або для повторної інтерпретації існуючих; 3) метод оцінювання. Оцінювальне дослідження стосується перевірки того, чи працюють правила на практиці, чи відповідають вони бажаним моральним, політичним, економічним цілям, чи відповідають законодавству, чи може працювати певна пропозиція щодо гармонізації з іноземним законодавством з урахуванням інших важливих розбіжностей у правовій системі. До інших особливих методологічних підходів належать: теорія раціонального вибору, теорія ігор, економічний аналіз права тощо 11.

Для створення методології правового дослідження важливими є ще декілька важливих аспектів.

1. Поступовий перехід від національного контексту правового дослідження до наднаціонального характеру такого контексту. Правова наука сформувалася як коментування учених до діючих текстів законів та прецедентного права (XIX ст.), однак на сьогодні вона не може бути вичерпана цим. В останні 30 років разом із процесами інтернаціоналізації, європеїзації та глобалізації правнича наука значною мірою стала іншою, заохочуючи поєднання коментування (аналізу) (проєкту) норм, судової практики та розвитку подій у національних юрисдикціях із подібними процесами у міжнародно-правовому ракурсі. Більш того, юридична наука зосереджується на дослідженні найкращих способів розробки законодавства та того, як правові норми слід застосовувати у конкретних випадках, наприклад, з огляду на єдність практики та правової визначеності12.

2. Для методологічного сприйняття правової реальності важливим є розуміння самого права, зокрема його співвідношення з іншими базовими регуляторами. У цьому контексті слід підтримати позицію, за якою національні та міжнародні системи цінностей випливають із загальних та спільних цінностей, таких як гідність, рівність та свобода. Ця позиція стверджує, що вказані цінності підтверджують дотримання основних прав людини. У цьому виявляється сприйняття того, що право є кодифікацією моральних поглядів суспільства. Дійсність будь-якого національного правового порядку грунтується на фундаментальних принципах гідності, рівності та свободи, які закріплені в багатьох правилах національних правових порядків, але по суті належать до категорій етики, моралі та справедливості. Основні права людини як норми національного та міжнародного права одночасно належать і до моралі та етики, а відтак, мають більше шансів бути гарантованими. Загальнолюдські цінності та основні права людини перетинаються, і таке перекриття цінностей та основних прав людини фіксує фундаментальну єдність між мовою права та мораллю. Отже, в цьому сенсі право - це концепція передових моральних принципів, яка є загальною для всіх учасників міжнародної спільноти i, як це загальновизнано, є пізнаваною лише людським розумом ${ }^{13}$.

3. Обрання певного методу дослідження на емпіричному рівні (описовий, герменевтичний чи нормативний?) відображає дилему правничої науки: з одного боку, правнича наука не може ігнорувати надто складного предмета дослідження (реальності права та його контексту), а, з іншого боку, розуміння того, що надто широкий предмет загрожує вийти на поле інших наук (юридична наука може просто не справитися 3 ним). Суто внутрішній аналіз правової системи, ізольований від будь-якого суспільного контексту, залишається варіантом і все ще спостерігається в підході багатьох учених, але оскільки право спрямоване на впорядкування суспільства та вплив на поведінку людини, такий підхід, як випливає з позиції багатьох, може бути недостатнім ${ }^{14}$.

4. Нарешті, методологія правового дослідження потребує ще одного - знаходження оптимального співвідношення емпіричного і теоретичного. Донедавна юридична наука демонструвала посилену увагу до емпіричних досліджень у розробці та оцінці права та політиці й практиці юридичних органів. Однак слід погодитися з особливою цінністю використання не лише емпіричних методів дослідження при оцінці існуючої політики та практики, а й теорій суспільних наук. Теоретичне дослідження дає основу для уявлення та тестування різних моделей щодо того, як може працювати правова система ${ }^{15}$.

Торкаючись оптимальної методики проведення дослідження (на відміну від його методології), слід зазначити, що в процесі проведення правового дослідження алгоритм дій наступний: 1) вибір координаційного центру дослідження; 2) огляд літератури; 3) постановка гіпотези; 4) дизайн досліджень; 5) збір даних; 6) аналіз даних; 7) інтерпретація даних; звіт. При цьому, звісно, слід мати на увазі, що право не знаходиться у вакуумі, воно діє в складному соціальному контексті. Воно відображає ставлення та норми поведінки, а також контролює та формує їх. Однак, оскільки ці норми є також часово-просторовими, тобто змінюються 3 часом та простором, бажано, щоб право могло адаптуватися та бути динамічним, щоб впоратися зі змінами. Важливим при цьому є соціальний аудит права (закону), щоби виявити дистанцію між юридичним ідеалом та соціальною реальністю, а також дізнатися про причини, що їх зумовили. Врешті, правове дослідження це систематичне розуміння права $з$ метою його вдосконалення i, виходячи з того, що право діє в суспільстві, у цьому процесі вони впливають один на одного ${ }^{16}$.

Варто звернути увагу на наступні методи дослідження правового явища.

Системний метод правового дослідження. У літературі його інколи називають систематичним контент-аналізом, який спрямований як на тексти (що завжди традиційно вчиняла юридична наука), так і на систематизацію емпіричних юридичних досліджень ${ }^{17}$. У рамках правничої науки України (наприклад, I. Заморська) найчастіше системний підхід сприймається як методологічний напрям, основне завдання якого полягає в розробці методів дослідження та у формуванні певних об'єктів - систем різних типів. Такий підхід насамперед припускає що право - це структурно-елементне утворення, первинним елементом якого 
$€$ правові норми, які для забезпечення найбільш ефективного регулювання окремих видів суспільних відносин об'єднуються у відповідні галузі, а також визначає правову нормативність як системне явище соціальної дійсності, яка проявляється через нормативно-правові приписи. Побудова всієї сукупності правових норм на основі певної послідовності та взаємозв'язку дає змогу говорити про складне, цілісне утворення систему права 18.

Доктринальний метод правового дослідження. Коли говорять про доктринальне правове дослідження, йдеться про дослідження юридичної концепції та принципів всіх типів справ, статутів (законів) і норм. Мета цього методу - стабільність та визначеність права. Цей спосіб дослідження охоплює систематичний аналіз законодавчого регулювання та правових принципів, що включаються або випливають із нього 3 метою їх логічного і раціонального впорядкування. Переважно такі дослідження проводяться суддями або ж викладачами права. До джерел доктринального дослідження належать: тексти законів, періодичні видання та коментарі, звіти комітетів парламенту, правові історії тощо ${ }^{19}$.

Історико-правовий метод дослідження. Для дослідження кожного правового явища важливим $є$ 3'ясування двох моментів функціонування явища: 1) інтелектуальної історії, пов’ язаної з ним; 2) його інституційної історії. Насправді на сьогодні чимало актуальних проблем юриспруденції стали розроблятися внаслідок інтересу до історії.

Історико-правовий підхід при цьому охоплює від короткої (в мікросоціальних вимірах) до глобальної інтелектуальної історії, перетворивши дискурс правової історії за його обсягами далеко за межі традиційних національних чи релігійних кордонів, він став міжнародним та порівняльним за обсягом і орієнтацією. Взаємозв'язок між правовою історією та історичним аналізом права є багатоаспектним ${ }^{20}$. Разом із тим, історикоправовий метод $є$ складовою методології, виступаючи історичним аналізом, він є видом критичного аналізу права, методом, який дає змогу подолати давнє і непродуктивне розмежування між «сучасною» і «традиційною» правничою наукою 21.

Історичний підхід часто визначає орієнтири, що показують, як все розвивалося і розвивалося 3 роками. Відомий вислів О. Холмса «Життя права - це не логіка; це досвід» проявляє одну важливу річ: досвід не можна оцінити, якщо ми не оцінимо історію. Іншими словами, як говорить індійський вчений Рабіндра K. Патак (Rabindra Kr. Pathak): «Наш досвід продовжує зберігатись у формі історії. Сьогоднішній досвід $є$ частиною історії завтрашнього дня. Досвід може бути інституційним або індивідуальним. Таким чином, історичний підхід до правових досліджень набуває великого значення для розуміння внеску, внесеного інституційно чи індивідуально в еволюцію та дію права». Цей же учений дійшов висновку, що історичний підхід до правових досліджень залишається відмінним щодо будь-якого іншого підходу, оскільки він забезпечує основу для аналізу розвитку права, а також дії права, як з внутрішньої, так і із зовнішньої точки зору. Особливо важливо, на його думку, врахувати величезний потенціал, який накопичує історичний підхід, стосовно його внеску до правових досліджень та розуміння того, як право працює як текстово, так і контекстуально і який взаємозв'язок обох результатів для творення права 22.

Висновки. По-перше, методологія дослідження правових явищ потребує оновлення, виходячи зі зміни правової парадигми, пов'язаної з розумінням права (співвідношенням із державою та ії функціями), та формуванням на початку XXI ст. правової реальності як на рівні національному, так і в міжнародно-правовому аспекті. По-друге, сучасна методологія правового дослідження продовжує перебувати в координатах важливої дилеми щодо співвідношення «чисто» юридичних методів дослідження і так званих «міждисциплінарних» підходів. По-третє, методологічний інструментарій (конкретні методи дослідження) правничої науки залишається невичерпним за змістом та особливо - за можливими комбінаціями їх уживання для досягнення пізнавального результату. На розширення їх каталогу впливає як розвиток юриспруденції та інших наук, їх гносеологічних складових, так і процеси глобалізації та інтернаціоналізації правового життя.

${ }^{1}$ Братасюк В. Особливості методологічного аналізу правової реальності. Електронний ресурс. Вісник Академії управління МВС. 2008. № 1-2. С. 74-87.

2 Фальковський А.О. Поняття та функції методологічних підходів у сучасних правових дослідженнях. Актуальні проблеми держави і права. 2009. Вип. 45. С. 40-44.

3 Фальковський А.О. Різноманітність аксіологічних підходів у методології права. Актуальні проблеми держави $і$ права. 2009. Вип. 50. С. 73-79. URL: http://nbuv.gov.ua/UJRN/apdp_2009_50_13

4 Сердюк О.В. Методологічні дослідження в правознавстві: зміна парадигм. Актуальні проблеми держсави і права. 2005. Вип. 24. С. 217-224. URL: http://nbuv.gov.ua/UJRN/apdp_2005_24_32

5 Дудченко В.В. Роль методології юридичної науки у становленні новаційного науково-правового мислення. Актуальні проблеми держави і права. 2003. Вип. 21. С. 13-17. URL: http://nbuv.gov.ua/UJRN/apdp_2003_21_3

${ }^{6}$ Кельман М.С. Методологічна ситуація у сучасному правознавстві та тенденції розвитку його методології. Науковий вісник Міжнародного гуманітарного університету. Юриспруденція. 2013. Вип. 5. С. 4-8. URL: http://nbuv.gov.ua/UJRN/Nvmgu_ jur_2013_5_3

7 Данильян О.Г. Теоретико-методологічні проблеми захисту прав людини в сучасному суспільстві. Вісник Національноі юридичної академії України імені Ярослава Мудрого. Серія : Філософія, філософія права, політологія, соціологія. 2013 . № 3. C. 84-91. URL: http://nbuv.gov.ua/UJRN/Vnyua 2013 $3 \quad 13$

8 Лук'янова Г.Ю. Методологічний пошук синтезу типів праворозуміння в сучасній українській юриспруденції. Європейські перспективи. 2012. № 2(2). C. 53-59. URL: http://nbuv.gov.ua/UJRN/evpe 2012 2(2) 11

9 Мережко О. До питання про можливість створення універсальної теорії права. Філософія права $і$ загальна теорія права. 2013. № 1. C. 180-182. URL: http://nbuv.gov.ua/UJRN/filpr_2013 1_17

10 Jan Pinz. Ancient Methodology in Architects\&\#39; First Aid // DNY PRÁVA 2013 - DAYS OF LAW 2013. Part I. Actual Otázky Ancient Methodology Eds : Miloš Vecer and Tatiana Machalová Jiř́ Valdhans. S. 81-91. URL: https://www.academia.edu/ 
7215406/Srokosz Jacek The American_discussion_on the value_of the Langdell_s_education_method_of_teaching_students to thinking like a lawyer_and possimulation ation in Palliance

${ }_{11}$ Miodrag Jovanovic. Legal Methodology \&amp; Legal Research and Writing. URL: http://www.ius.bg.ac.rs/prof/materials/ jovmio/mei/Legal\%20methodology\%20and\%20legal\%20research\%20and\%20writing.pdf

12 Philip Langbroek, Kees van den Bos, Marc Simon Thomas, Michael Milo, Wibo van Rossum Legal Research Methodology: Challenges and Opportunities.

13 Jernej Letnar. International value system, fundamental human rights and law. Nova Gorica, October 15-16, 2009 European Faculty of Law in Nova Gorica Slovenia. URL: https://www.evro-pf.si/media/website/2013/04/knjizica LegArg2009-final-PDF.pdf

${ }_{14}$ Legal Research Methodologies. Which Kind of Method for What Kind of Discipline? Editor: Mark Van Hoecke. 28-02-2011 1st. 310. URL: https://www.bloomsburyprofessional.com/en/methodologies-of-legal-research-9781847317803/

15 Tyler, Tom, Methodology in Legal Research (December 12, 2017). Utrecht Law Review, Vol. 13. No. 1 3. P. 130-141, 2017. Available at SSRN. URL: https://ssrn.com/abstract=3128268

16 Legal research. Prof. dr. (Dr.) Ranbir Singh. Prof. dr. (Dr.) G.S. Bajpai. URL: http://epgp.inflibnet.ac.in/epgpdata/uploads/ epgp_content/law/09._research_methodology/02._legal_research/et/8149_et_et.pdf

17 The Value of Systematic Content Analysis in Legal Research. Maryam Salehijam. International Journal of Law. Volume 3; Issue 5; September 2017. P. 128-130.

18 Заморська Л.І. Системний підхід у дослідженні правової реальності. Вісник північного регіонального ичентру Національної академї̈ правових наук України. 2016. № 7. С. 38-44. URL: http://nbuv.gov.ua/UJRN/vprc_2016_7_6

19 Vijay M Gawas. Doctrinal legal research method a guiding principle in reforming the law and legal system towards the research development.

${ }^{20}$ Bryan Wagner. Historical Method In The Study of Law And Culture. The Oxford Handbook of Legal History. Edited by Markus D. Dubber and Christopher Tomlins. URL: https://www.oxfordhandbooks.com/view/10.1093/oxfordhb/9780198794356.001.0001/ oxfordhb-9780198794356

${ }^{21}$ Dubber, Markus D., Legal History As Legal Scholarship: Doctrinalism, Interdisciplinarity, and Critical Analysis of Law (July 13, 2017). Oxford Handbook of Historical Legal Research, 2016. Available at SSRN. URL: https://ssrn.com/abstract=3002587

${ }_{22}$ Rabindra Kr. Pathak. Historical Approach to Legal Research. URL: https://www.researchgate.net/publication/336676844_Historical_Approach_to_Legal_Research

\section{Резюме}

Копча В.В. Методологія дослідження правового явища: поняття, структура, інструментарій.

Ця стаття спрямована на дослідження методології правового явища. При цьому особливу увагу було приділено таким аспектам, як з'ясування основних підходів до розуміння методології та ії співвідношення з методикою дослідження; дослідження обсягу та структури поняття методології; окреслення основних методів дослідження.

Автором зроблено висновки за результатами дослідження. По-перше, методологія дослідження правових явищ потребує оновлення, виходячи зі зміни правової парадигми, пов'язаної з розумінням права (співвідношенням із державою та іiі функціями), та формуванням на початку XXI ст. правової реальності як на рівні національному, так і в міжнародно-правовому аспекті. По-друге, сучасна методологія правового дослідження продовжує перебувати в координатах важливої дилеми щодо співвідношення «чисто» юридичних методів дослідження і так званих «міждисциплінарних» підходів. По-третє, методологічний інструментарій (конкретні методи дослідження) правничої науки залишається невичерпним за змістом та особливо - за можливими комбінаціями їх уживання для досягнення пізнавального результату. На розширення їх каталогу впливає як розвиток юриспруденції та інших наук, їх гносеологічних складових, так і процеси глобалізації та інтернаціоналізації правового життя.

Ключові слова: право, методологія дослідження, методи дослідження, системний метод, догматичний метод, історикоправовий метод.

\section{Резюме}

Копча В.В. Методология исследования правового явления: понятие, структура, инструментарий.

Эта статья направлена на исследование методологии правового явления. При этом особое внимание было уделено таким аспектам, как выяснение основных подходов к пониманию методологии и ее соотношение с методикой исследования; исследование объема и структуры понятия методологии; определение основных методов исследования.

Автором сделаны выводы по результатам исследования. Во-первых, методология исследования правовых явлений нуждается в обновлении, исходя из изменения правовой парадигмы, связанной с пониманием права (соотношением с государством и его функциями), и формированием в начале XXI в. правовой реальности как на уровне национальном, так и в международно-правовом аспекте. Во-вторых, современная методология правового исследования продолжает находиться в координатах важной дилеммы о соотношении «чисто» юридических методов исследования и так называемых «междисциплинарных» подходов. В-третьих, методологический инструментарий (конкретные методы исследования) юридической науки остается неисчерпаемым по содержанию и особенно - за возможными комбинациями их употребления для достижения познавательного результата. На расширение их каталога влияет как развитие юриспруденции и других наук, их гносеологических составляющих, так и процессы глобализации и интернационализации правовой жизни.

Ключевые слова: право, методология исследования, методы исследования, системный метод, догматический метод, историко-правовой метод.

\section{Summary}

Vasyl Kopcha. Methodology of legal phenomenon research: concept, structure, tools.

This article is aimed at exploring the methodology of the legal phenomenon. Particular attention was paid to such aspects as clarifying the main approaches to understanding the methodology and how it relates to the research methodology; study of the scope and structure of the concept of methodology; outlining the main research methods.

The author draws conclusions from the results of the study. First, the methodology for the study of legal phenomena needs to be updated based on a change in the legal paradigm associated with the understanding of law (relation to the state and its functions) and the formation of legal reality at the beginning of the 21 st century both at national and international level. the legal aspect. Secondly, the current methodology of legal research continues to be in the co-ordinates of an important dilemma regarding the correlation of "purely" legal research methods and so-called "interdisciplinary" approaches. Third, the methodological tools (specific research methods) of 
legal science remain inexhaustible in content and, in particular, in the possible combinations of their application to achieve a cognitive result. The extension of their catalog is influenced by the development of jurisprudence and other sciences, their epistemological components, and the processes of globalization and internationalization of legal life.

Concerning the optimal research methodology (as opposed to its methodology), it should be noted that in the course of legal research the algorithm of actions is as follows: 1) selection of the research coordination center; 2) literature review; 3) hypothesis formulation; 4) research design; 5) data collection; 6) data analysis; 7) interpretation of data; report. Of course, it should be borne in mind that law is not in a vacuum, it operates in a complex social context. It reflects and controls attitudes and behaviors. However, as these rules are also temporal and spatial, that is, they change with time and space, it is desirable that law can adapt and be dynamic to cope with change. Important is the social audit of law (law) in order to identify the distance between the legal ideal and social reality, as well as to find out the reasons that led them. After all, legal research is a systematic understanding of law in order to improve it and, given that law operates in society, in the process they influence one another.

Key words: law, research methodology, research methods, system method, dogmatic method, historical and legal method.

DOI: 10.36695/2219-5521.1.2020.09

УДК 340.13

\section{о.в. МИнькОвич-СлоБодяник}

Олена Василівна Минькович-Слободяник, кандидат юридичних наук, доцент, завідувач кафредри МІП Національного університету "Одеська юридична академія»*

ORCID: 0000-0003-2753-1031

\section{НЕГАТИВНІ ФАКТОРИ, ЩО ВПЛИВАЮТЬ НА РОЗВИТОК ПРАВОВОЇ ТА ПОЛІТИЧНОЇ КУЛЬТУР: ДО ПОСТАНОВКИ ПРОБЛЕМИ}

Правова і політична культури є явищами, що втілюють в собі надбання певного суспільства за конкретний період часу в правовій та політичній сфері. Говорячи про часовий проміжок, ми пов'язуємо розвиток чи занепад даних явищ з історичними та економічними чинниками, які впливають на них. Природно, що сучасна українська правова та політична культури теж проходять стадію свого розвитку, і в цьому контексті важливо зрозуміти, яким чином, в який спосіб і що є підгрунтям для даних факторів.

Метою даної статті $є$ аналіз саме негативних факторів, які виявляються гальмуючим і послаблюючим чинником на шляху розвитку правової та політичної культур сучасної України.

Дослідженням цієї проблематики в різні часи займалися такі вчені, як: О.Ю. Бусол, Л.О. Макаренко, О.В. Білоруська, І.В. Кушнарьов та ін.

Будь-які негативні фактори, що існують в громадянському суспільстві, відбиваються й на правовій та політичній культурі. Одним із таких чинників, на наш погляд, є корупція. Вона як ракова пухлина сьогодні роз'їла державницький апарат і призвела до тотальної зневіри у суспільстві як до права (регулятора суспільних відносин і «ідеального» мірила справедливості), так і до політики (як мистецтва можливого компромісу). Українське суспільство мало сьогодні вірить судовим і правоохоронним органам, майже не довіряє політикам, у кожному чиновнику пересічний громадянин (втім, як і більшість у суспільстві) бачать корупціонера-злочинця.

Термін «корупція» походить від латинських слів «соrrei» (кілька учасників, що вступають у відносини 3 приводу одного предмета) i «rumpere» (ламати, пошкоджувати, порушувати, скасовувати). Які в підсумку утворюють самостійний термін «корупція», що передбачає участь у діяльності кількох осіб, метою яких $€$ «гальмування» нормального судового процесу або процесу управління справами суспільства ${ }^{2}$.

На думку М. Колодяжного, корупція - це сучасне негативне явище соціальної дійсності, своєрідний супутник приватних і публічних відносин в усіх сферах діяльності органів влади та управління. Вона наскільки укорінилася у свідомості як державних службовців, так і пересічних українців, що сприймається усіма як щось належне, природне та віками притаманне національному менталітету і культурі. Не буде перебільшенням, якщо пов'язувати сучасну корупцію в Україні з глибокою соціально-економічною кризою, що зумовлює бідність понад 80 \% українців, широкою майновою поляризацією населення, безробіттям, фінансовою та банківською нестабільністю; розбалансуванням діяльності органів державної влади і місцевого самоврядування; гальмуванням реформування правоохоронної сфери; складнощами євро інтеграційних процесів України тощо 2 .

Взагалі науковці сьогодні дали досить багато визначень корупції. Оскільки дане явище є багатоаспектне, то в юриспруденції, політології, соціології, економіці фахівці звертають увагу на різні його аспекти, але всі сходяться в одному, що воно є злочинною діяльністю, яка полягає у «використанні посадовими особами наданих їм прав і владних можливостей з метою особистого збагачення»³.

(C) О.В. Минькович-Слободяник 2020

\footnotetext{
* Olena Minkovich-Slobodianik, Ph.D. in Law, Associate Professor, Head of department of MIL National University "Odessa Law Academy"
} 